\title{
Ecological role of crop rotation in the efficient use of agricultural territories of the forest- steppe zone of the Volga region
}

\author{
Alexander Toigildin*, Vladimir Morozov, Mikhail Podsevalov, Irina Toigildina, and Denis \\ Ayupov
}

Ulyanovsk State Agrarian University named after P.A. Stolypin, 432017 Ulyanovsk, Russia

\begin{abstract}
The article presents the results of a theoretical review of the role of the structure of cultivated areas and crop rotations in agriculture. Based on experimental studies, recommendations are given for optimizing the structure of cultivated areas and the system of crop rotations in the forest-steppe zone of the Volga region. The structure of sown areas and crop rotations should expand the species composition of cultivated crops, introduce intermediate crops. Our research shows that the structure of sown areas should reduce the proportion of pure fallow to $40 \%$ of the area with winter grain crops to increase the productivity of arable land, protect the soil from erosion, preserve and reproduce its fertility. At the same time, it is necessary to increase the area of perennial leguminous grasses and legume-cereal mixtures and bring their share to $25 \%$ of the cultivated area. This requires introducing grain-grass and fruit crop rotations, which will improve the ecological state of the soil and crops, and ensure the reproduction of soil fertility.
\end{abstract}

\section{Introduction}

The world community has formed the concept of "sustainable development"; Russia, in turn, has legislative acts regulating the functioning of the economy in the course of sustainable development. As for agriculture, today the Federal Target Program of Sustainable Development of Rural Areas of the Russian Federation for 2014-2017 and until 2020 is applied. This program outlines specific tasks to achieve the aggregate economic effect, including through a significant increase in agricultural production.

The model of sustainable development of agriculture as a branch of the agro-industrial complex is associated with its alignment with the requirements of environmental laws. Thus, it is appropriate to use the term "ecological direction, ecological course" - "the process of consistently introducing the ideas of nature conservation and environmental sustainability in legislation, management, technology development, economics, education, etc." [1]. In crop production, this principle is implemented through the biologization of agricultural technologies and farming systems in general. Biologization (direction) and biological farming (method of land use) are aimed at reducing the negative consequences of

*Corresponding author: atoigildin@yandex.ru 
intensification factors. The essence of agriculture biologization is to enhance the role of biotic factors in the agroecosystems.

The forest-steppe zone of the Volga region refers to the territory where agriculture is an important branch of the economy, therefore, the sustainable development of the agroindustrial complex is a priority of the government, industry, and science.

However, many researchers [2, 3, 4] note an irrational use of agricultural land in the Volga region, the unbalanced structure of sown areas, which is explained by unstable demand for individual crop products, and thus "commercial" crops prevail - winter wheat, barley, sunflower, and some others. At the same time, the fundamental principles of sustainable development of farming systems, such as the law of fruit rotation and biodiversity, are violated.

The number of publications on theoretical issues of optimizing the structure of sown areas and rational crop rotations has decreased, although this issue is key in the development of a farming system and a strategy for the development of regional agriculture; world practice, however, shows the promise of directions for studying the issues of improving crop rotations and optimizing crop areas [5, 6, 7, 8, 9].

In recent years there have been significant changes in climate and environmental conditions for humans, animals, and plants in many regions of Russia [10; 11]. Global warming is noted and the concentration of $\mathrm{CO}_{2}$ in the atmosphere is increasing. "According to forecasts of the international climate organization - the Intergovernmental Panel on Climate Change (IPCC, Switzerland), by the end of the XXI century the Earth's temperature will increase significantly (up to $4.6^{\circ} \mathrm{C}$ )" [12]. Against this background, there is a gradual introduction of new crops from the southern to the northern regions of Russia, "while grain production in Russia may increase 2.0 times due to a northward shift of the border of agricultural" [13]. For example, in the Volga region in recent years, the cultivation of corn for grain, chickpeas, soybeans, and other crops, which require a comprehensive assessment, has become more widespread.

Insufficient development of animal husbandry causes less cultivation of fodder crops, and perennial grasses occupy an insignificant area in the structure of sown areas; against this background, organic fertilizers are practically not used, so there is no need to talk about expanded reproduction of soil fertility $[14,15]$.

Studies show that $17.7 \%$ of agricultural land of Russia is subject to water erosion, of which arable land is $12 \%$, while an increase in eroded land by 1.5 million hectares is noted annually, which leads to a significant shortage of crop production and large ecological and economic consequences. According to various estimates, the grain shortfall is estimated at 15.8 million tons per year [16].

On the territory of the Ulyanovsk region, 300 thousand hectares of agricultural land are susceptible to water erosion, including arable land - 226 thousand hectares, wind erosion (deflation) - 3.28 thousand hectares of agricultural land, including 2.19 thousand hectares of arable land [17]. To protect lands from erosion, it is necessary to justify the structure of crop rotations and develop crop rotations in such a way to regulate water flow and prevent soil washout, as well as to ensure a deficit-free regime of organic matter.

Sustainable development of rural areas should be based on the efficient use of agricultural land, which requires, first of all, the development of livestock, optimization of the structure of sown areas, and the development of effective crop rotations that ensure the reproduction of soil fertility.

The objective of the research is to substantiate the role of the structure of cultivated areas and crop rotation schemes in the sustainable development of rural areas in the foreststeppe zone of the Volga region. 


\section{Materials and Methods}

The role of crop rotations in the sustainable development of territories was assessed based on the review of the literature using a systematic analysis. Also, the experimental study of various types and kinds of crop rotations in the yield formation, the assessment of the productivity of arable land and their role in protecting soils from erosion processes was carried out in a stationary field experiment of the Department of Agriculture, Plant Growing and Selection of the Ulyanovsk State Agrarian University in 2004-2020. The soil of the experimental site is leached medium-thick medium-loam chernozem.

The studies were carried out in the forest-steppe zone of the Volga region, which is located in the basin of the Middle Volga and occupies the eastern edge of the vast Russian Plain. The territory of this zone includes the Ulyanovsk and Penza regions, the northern parts of the Samara region, and the southern parts of the Republic of Tatarstan. The zone is approaching a normal moisture level; it has a temperate continental climate, except for some parts of the southern regions and the Trans-Volga region.

\section{Results and Discussion}

Analysis of the structure of cultivated areas in the region.

The scientific basis for a systematic solution to the problem of effective use of agricultural land is the structure of cultivated areas. Land ownership imposes social responsibility on rural commodity producers for the efficient and rational use of land, production of the required range of goods with minimal costs, and in the required amount.

Over the past five years, the sown area of cultivated lands in the Ulyanovsk region has increased from 1010.2 thousand hectares to 1054.1 thousand hectares, or by 43.9 thousand hectares. The increase was mainly due to the grain group of food crops, primarily winter wheat and barley. As a result, such changes in the structure of cultivated areas ensured an annual increase in grain production compared to 2015.

In the current economic and market situation, rural commodity producers focus mainly on the production of food grains and some industrial crops, primarily sunflower, which in 2020 accounts for more than 225.4 thousand hectares or $21.4 \%$ of the cultivated area (Table 1).

Remarkably, valuable leguminous crops occupy only 13.8 thousand hectares or less than $1.3 \%$ in the structure of cultivated areas. Considering the agrotechnical requirements, the needs of animal husbandry for vegetable protein, and the indicators achieved in previous years, these figures are extremely insignificant and should be increased several times. Note that in 1990 the production of leguminous crops was 282.5 thousand tons, including 268.2 thousand tons of peas. At the same time, the share of legumes in the gross harvest of cereals of 13.3 and $12.6 \%$, respectively, was within the scientifically grounded standards.

In general, the share of forage crops remains extremely low due to the insufficient development of animal husbandry. Thus, the area of forage crops over 5 years has decreased from 169 thousand hectares to 118.4 thousand or 50.6 thousand hectares, while perennial grasses in 2020 occupy 57.5 thousand hectares.

In the structure of cultivated areas, the grain group accounts for $61.4 \%$. With such a high saturation of crop rotations with cereals due to a small share in crops of such predecessors as legumes, industrial crops (rape, mustard, flax, etc.), perennial grasses, part of the crops of winter cereals will be used in crop rotations after non-fallow (spike) predecessors, as well as in repeated crops of grain. These conditions caused an increase in phytosanitary tension and soil fatigue of the fields, which leads to a decrease in yield and product quality. 
The unbalanced structure of cultivated areas and climatic changes lead to shifts in the geographical distribution of phytopathogenic fungi species. "Research shows that global warming is driving the spread of thermophilic fungi from south to north. Soil warming stimulates the activity of Pyrenophora, Septoria, Pythium, Rhizoctonia, Sclerotinia soil fungi, reduces the latent period of disease development, and increases the aggressiveness of pathogens" [18]. Environmental changes and man-made impacts have led to a change in the species composition of agricultural pests and weeds. For example, in the forest-steppe zone of the Volga region, according to our observations, new species of weeds have appeared in agrophytocenoses in recent decades - Galinsoga parviflora, Amaranthus blitoides, Reseda lutea, etc.

Table 1.The structure of the cultivated areas of the Ulyanovsk region in farms of all categories in 2015 and 2020 [19]

\begin{tabular}{|l|c|c|c|c|c|}
\hline \multirow{2}{*}{ Crops } & \multicolumn{2}{|c|}{2015} & \multicolumn{2}{c|}{2020} & $\begin{array}{c}\text { Deviation } \\
\text {-+, thousand } \\
\text { ha }\end{array}$ \\
\cline { 2 - 5 } & $\begin{array}{c}\text { thousand } \\
\text { ha }\end{array}$ & $\%$ & $\begin{array}{c}\text { thousand } \\
\text { ha }\end{array}$ & $\%$ & +67.6 \\
\hline Cereals and grain legumes & 579.2 & 57.3 & 646.8 & 61.4 & +20.2 \\
\hline Winter cereals & 287.2 & 28.4 & 307.4 & 29.2 & +47.4 \\
\hline Spring cereals & 292.0 & 28.9 & 339.4 & 32.2 & +1.7 \\
\hline grain legumes & 12.1 & 1.2 & 13.8 & 1.3 & +3.7 \\
\hline cereals & 5.6 & 0.6 & 9.3 & 0.9 & +35.9 \\
\hline Technical & 233.3 & 23.1 & 269.2 & 25.5 & +39.4 \\
\hline sunflower & 186.0 & 18.4 & 225.4 & 21.4 & -9.1 \\
\hline Potatoes, vegetables and melons & 28.7 & 2.8 & 19.6 & 1.9 & -50.6 \\
\hline Fodder & 169.0 & 16.7 & 118.4 & 11.2 & -5.5 \\
\hline perennial grass & 83.2 & 8.2 & 57.5 & 5.5 & -25.7 \\
\hline Total cultivated area & $\mathbf{1 0 1 0 . 2}$ & $\mathbf{1 0 0 . 0}$ & $\mathbf{1 0 5 4 . 1}$ & $\mathbf{1 0 0 . 0}$ & $\mathbf{+ 4 3 . 9}$ \\
\hline
\end{tabular}

The practice of reducing the species diversity of agricultural crops in crop rotations reduces the possibilities of efficient use of agro-climatic and other resources and leads to unstable production in the crop farming sector.

A rational combination in the structure of sown areas of crops with different biological characteristics, different sowing and harvesting times ensures a more rational and efficient use of hydrothermal factors, equipment, labor resources, etc. and has both economic (more sustainable production) and agrotechnical importance.

Crop rotation models for sustainable development of territories.

The essence and role of crop rotation in the sustainable functioning of agricultural landscapes and territories are not just to change crops in the fields; it performs several functions. First, crop rotation is an analog of succession - a sequential change of phytocenoses; crop rotation is an agroecosystem with its cycle of matter (energy) and changes in soil fertility indicators; it is its ecological essence. Secondly, crop rotation regulates the organic matter regime and determines the phytosanitary state of soil and crops, which determines its biological essence. Thirdly, crop rotation reflects the structure of cultivated areas and specialization of agricultural enterprises, which is its economic essence.

In our opinion, a theoretically grounded alternation of crops and fallows and the crop rotation system presupposes and provides:

- a control effect on the production process of plants (seeds, variety, fertilizers, plant protection products, technology in general, etc.); 
- the regime of organic matter and other indicators of soil fertility (accumulation of biogenic resources for reproduction of soil fertility - agrophysical, agrochemical, and agrobiological indicators);

- the competitiveness of crops in agrophytocenoses, relief of phytosanitary tension and soil fatigue (implements the phytocenotic method of protecting plants from harmful organisms);

- rational use of moisture resources and elements of mineral nutrition of plants (with fruit rotation - alternation of crops with different biological characteristics);

- involvement in the biotic cycle of resources of symbiotic nitrogen and other nutrients (primarily legumes and their mixtures with a cereal component);

- protection of soils in erosion-dangerous agricultural landscapes (design soil coverage due to perennial grasses, ground cover crops, etc.);

- integration of the elements of the farming system into a single technological complex (by developing and substantiating a rational farming system);

- production, environment-forming, and nature protection functions of agricultural landscapes (as a result of the above functions).

Summarizing the theoretical and experimental material, we can formulate the following principles for the development of crop rotations, their essence, and functions, as well as the prospects for their use for the sustainable functioning of agricultural land (Table 2).

Table 2. Principles for the development and the prospects for the use of crop rotations within the sustainable functioning of agricultural land in the forest-steppe zone of the Volga region.

\begin{tabular}{|c|c|c|}
\hline No. & Crop rotation principles & $\begin{array}{l}\text { The essence and prospects for the sustainable functioning of } \\
\text { agricultural land }\end{array}$ \\
\hline 1 & Adaptability & $\begin{array}{l}\text { Cultivation of crops that most fully implement the bioclimatic } \\
\text { potential of the forest-steppe zone of the Volga region. Flexibility } \\
\text { in introducing promising crops (sorghum, safflower, chickpea, } \\
\text { lupine, etc.) into crop rotations, which optimizes the structure of } \\
\text { cultivated areas and ensures the accumulation of organic matter } \\
\text { and the reproduction of soil fertility. }\end{array}$ \\
\hline 2 & Fruit rotation & \multirow[b]{3}{*}{$\begin{array}{l}\text { The principles of fruit rotation and periodicity provide } \\
\text { biodiversity, maintenance of microbiological soil activity, } \\
\text { alternation of crops with fibrous and tap root systems, the use of } \\
\text { pesticides of various groups, which will reduce the intensity of } \\
\text { mechanical soil cultivation and the amount of use of chemical } \\
\text { plant protection products. } \\
\text { Intermediate crops provide a time gap between major crop groups, } \\
\text { especially in specialized (grain) crop rotations. The conditions of } \\
\text { the forest-steppe zone of the Volga region are suitable for the } \\
\text { cultivation of green manures after harvesting winter and spring } \\
\text { grain crops to increase the coefficient of land use. }\end{array}$} \\
\hline 3 & Periodicity & \\
\hline 4 & $\begin{array}{l}\text { Compacted use of } \\
\text { arable land. }\end{array}$ & \\
\hline 5 & $\begin{array}{l}\text { Biological and } \\
\text { economic feasibility. }\end{array}$ & $\begin{array}{l}\text { Alternation of early spring, late spring, cereal, and dicotyledonous } \\
\text { plants in the fields, the introduction of commercial crops, as a } \\
\text { result of maintaining biodiversity in agrophytocenoses and } \\
\text { reproduction of soil fertility. }\end{array}$ \\
\hline 6 & Specialization & \multirow[b]{2}{*}{$\begin{array}{l}\text { Under intensive farming, the construction of specialized crop } \\
\text { rotations for cereals, oilseeds, legumes, industrial and other crops. } \\
\text { Saturation of crop rotations with crops of one group, which } \\
\text { requires intensive soil cultivation, the use of plant protection } \\
\text { chemicals, the widespread use of catch crops with different types } \\
\text { of plants to obtain two harvests per year. }\end{array}$} \\
\hline 7 & $\begin{array}{l}\text { Compatibility and self- } \\
\text { compatibility }\end{array}$ & \\
\hline
\end{tabular}

Summarizing the material presented in the table, the following ways for improving the structure of cultivated areas should be outlined to maintain sustainable development of rural areas:

- alternate crops in crop rotations based on the principles of fruit rotation: cereals dicotyledonous - cereals; winter crops - early spring - late spring, etc.; 
- introduce intermediate (cover, post-harvest, post-cut, etc.) crops into crop rotations to obtain two harvests per year, including for feed, green fertilizer, and other purposes;

- reduce the proportion of pure vapors to the optimum possible level - no more than $40 \%$ (based on moisture availability, possible terms, technical capacity, etc.);

- introduce perennial grasses (alfalfa, sainfoin, clover, etc.) into crop rotations, first of all, legume-cereal phytocenoses;

- mandatorily introduce grain-grass crop rotations in erosion-hazardous areas of the territory.

The studies carried out in the forest-steppe zone of the Volga region allow us to recommend methods for improving the system of crop rotation, aimed at the sustainable functioning of agricultural landscapes.

As the data shows, a significant area of winter wheat is cultivated in dead fallow, which provides its higher yield; however, dead fallow is accompanied by erosion processes, loss of organic matter due to intensive mineralization, migration of mineral nutrition elements outside the root layer. According to our research, the productivity of crop rotation links with sown fallows is higher than with the dead fallow. The 15-year-long research allowed us to build an economic and mathematical model, according to which the optimal ratio of steam predecessors for winter wheat - dead fallow: sown fallow (including green manure) is $1: 1.5$ or 40 to $60 \%$. An increase in the share of sown fallows in crop rotations will increase the productivity of arable land and ensure the highest economic efficiency in the use of agricultural land.

"In this zone, together with the fallow links of crop rotations, the legumes links of crop rotations should be used: peas - winter wheat, lupine - winter wheat and peas + lupine winter wheat" [20]. The inclusion of legumes in crop rotation contributes to a decrease in the volume of nitrogen fertilizers - the main pollutants of groundwater and also ensures the production of forage resources for animal husbandry and soil fertility reproduction. Our research shows also the need to introduce the links of crop rotation with oilseeds: white mustard - winter wheat, spring rape - winter wheat, and oil flax - winter wheat.

Perennial grasses are important in improving the structure of sown areas and crop rotations. Mixtures of perennial legumes and cereal grasses are effective in enhancing biologization of crop rotations and are more productive in comparison with their singlespecies crops. In modern agriculture, the role of crop rotations is growing not only in increasing the productivity of crops, reproducing soil fertility but also in soil-protecting ability. According to our calculations, grain-grass crop rotations have a higher soilprotecting capacity in comparison with other types of crop rotations. The ability of crops to protect soils from erosion is determined by the set and ratio of crops in crop rotation, i.e. accumulated biomass and duration of stay in the field. Therefore, based on the weighted average projective soil coverage by crops in protecting land from water and wind erosion, grain-grass crop rotations are 2 times more effective than grain-fallow crop rotations. Grain-and-grass crop rotations improve the ecological state of the soil and crops, which is reflected in the reproduction of soil fertility.

\section{Conclusion}

Agriculture is an industry that has a major impact on the development of rural areas. The use of agricultural land is characterized by the structure of cultivated areas and the system of crop rotation in agricultural enterprises. This aspect determines the sustainability of agricultural landscapes. According to studies, the crop structure of recent years includes marketable crops, which forces the cultivation of crops such as winter wheat, barley, and sunflower. Crops that have an environment-forming function - legumes and perennial grasses - are almost absent or account for a small share in crop rotations. The share of dead 
fallow remains high in crop rotations. All this exacerbates the problem of soil fertility degradation, the negative regime of soil organic matter, erosion processes on arable land, a decrease in productivity and cost recovery in production, therefore there is a need to develop and theoretically substantiate the structure of sown areas and a system of crop rotations on principles aimed at solving the noted problems with minimal costs.

We recommend the agricultural enterprises in the forest-steppe zone of the Volga region to implement the following actions in their crop rotation systems:

- develop and theoretically substantiate the structure of sown areas and the system of crop rotations on the basic principles (adaptability; fertility; frequency; compacted use of arable land; biological, economic and economic feasibility; specialization; compatibility and self-compatibility), expand biodiversity by introducing promising main and intermediate crops in crop rotations;

- reduce the share of dead fallow to $40 \%$ of the cultivated area of winter grain crops and increase the area of sown fallow (legumes and oilseeds);

- introduce crops of perennial leguminous grasses more widely, at least $25 \%$ of the cultivated land area; for this, grain-grass crop rotations should be applied; and increase productivity and efficiency in the biologization system through the cultivation of crops in complex phytocenoses.

\section{Acknowledgments}

This work has been implemented under the support of grant MD-2909.2019.11.

\section{References}

1. Iu.Ia. Spiridonov, M.S. Sokolov, A.P. Glinushkin, et al., Adaptive-integrated plant protection, 619 (2019)

2. N.V. Shramko, G.V. Vikhoreva, Arable farming, 6, 15 (2012)

3. Iu.N. Pleskachev, A.N. Sukhov, V.Iu. Misuriaev, Arable farming, 2, 3 (2013)

4. V.I. Morozov, S.V. Basenkova, Bulletin of Ulyanovsk State Agricultural Academy, 2(26), 33 (2014)

5. K.T.Osman, Management of Soil Problems,1-474m (2018)

6. M.A. Altieri, Agroecology: The Science of Sustainable Agriculture (2018)

7. H. Lambers, R.S. Oliveira, Plant physiological ecology (2019)

8. A. Hamidov, K. Helming, D.Balla, Agronomy for Sustainable Development, 36(1), 1 (2016)

9. XuanYang, Zhou Li, Song Cui, Agricultural Water Management,229, 105959 (2020)

10. O.I. Gorianin, Cultivation of field crops in the Middle Trans-Volga region (2019)

11. K. Crumpler, M. Bernoux, Climate Change Management, 1, (2020)

12. The melting beauty. Climate change and its consequences (2009)

13. E. Lioubimtseva, N. Dronin, and A. Kirilenko, Food Agriculture Organization of the (2015)

14. V.I. Kiryushin, Theory of adaptive landscape farming and designing agrolandscapes (2011)

15. V.G. Loshakov, Crop rotations and fertility of the soil (2012)

16. Atlas of natural and man-made hazards and risks of emergencies. Russian Federation: collective monograph (2010) 
17. A.V. Dozorov, V.A. Isaichev, S.N. Nikitin, K.I. Karpovich et al., Adaptive landscape farming system of the Ulyanovsk region (2nd edition, revised) (2017)

18. M.M. Levitin, Agricultural biology, 50 (2015)

19. The territorial body of the Federal State Statistics Service for the Ulyanovsk region,https://uln.gks.ru/

20. A.L. Toigildin, V.I. Morozov, M.I. Podsevalov, Y.M. Isaev, I.A. Toigildina, Research Journal of Pharmaceutical, Biological, and Chemical Sciences, 7 (6), 2203 (2016) 